\title{
IMPACTS OF DETERMINANTS ON THE SUCCESS OF CROWDFUNDING CAMPAIGNS
}

\author{
${ }^{1,2}$ Quoc Dat Trinh, ${ }^{1,2}$ Le Hoai Phuc Nguyen \\ ${ }^{1}$ School of Business - International University, Vietnam \\ ${ }^{2}$ Vietnam National University, Ho Chi Minh City, Vietnam
}

DOI: 10.46609/IJSSER.2020.v05i07.008 URL: https://doi.org/10.46609/IJSSER.2020.v05i07.008

\begin{abstract}
This research concentrates on investigating critical determinants of the success of crowdfunding campaigns in Vietnam to the extent of a larger international scale. The study found that while the levels of reward and the ability of further information access on the campaign's owner are positively related to the success of the crowdfunding campaigns and the number of backers in both Vietnamese and foreign platforms, the goal of funding set at the beginning of each project is found at a contrary signal. The result becomes diverse with the length of the main content description of each crowdfunding project. We found a negative relationship between context length and the number of backers supporting campaigns launched on Vietnamese crowdfunding platforms, whereas it is positive for foreign crowdfunding campaigns.
\end{abstract}

Keywords: Crowdfunding, crowdfunding, financing source, success, crowd, backer, campaign, project, startup, entrepreneur.

\section{List Of Abbreviation Words}

CF: Crowdfunding

CFP: Crowdfunding Platform

KS: Kickstarter

IGG: Indiegogo 
International Journal of Social Science and Economic Research

ISSN: $2455-8834$

Volume: 05, Issue: 07 "July 2020"

\section{INTRODUCTION}

A raw project of having an idea, conducting, and developing it, seems not easy to be funded from financial institutions due to the lack of reciprocal capital as well as the uncertainty and/or fluctuation in future returns. To deal with this situation, many other external financing sources can help them have the ability to raise funding (Collins \& Pierrakis, 2012). A term called "Fintech", a fusion between finance and technology, was born. And crowdfunding (CF), a new form of informal venture financing via the Internet, was created from it. Crowdfunding can be thought of as the youngest, newest type of funding channel compared to other financing sources. This enhances the probability of getting entrepreneurs' ideas off the ground by directly attracting the general public online. For instance, start-ups and small and medium-sized enterprises (SMEs) often face with the difficulties surrounding financial issues, plus the financial crisis has sometimes made this fund shortage even more problematic (Moncada- Paternò-Castello, Vezzani, Hervás, \& Montresor, 2014). Theoretically, both SMEs and startups can finance internally (by using retained earnings and personal equity) and/or externally. However, start-up entrepreneurs have limited choices as they do not have much retained earnings, and if they do not have personal equity either, they must turn to external financing. CF may offer an alternative method of funding for SMEs and startups and filling the financing gap (Collins \& Pierrakis, 2012). A CF campaign contains three sides: a crowdfunding platform (the intermediary side), the project owner (can also be called the CF campaign creator), and the contributors who donate capital (called as backers afterward). The purpose of the campaigns is to raise funds for either profit or non-profit projects or organizations. Theoretically, there are four types of CF models choices which the CFPs are able to offer to the campaigners: Lending- based (peer-to-peerbased); Donation-based; Equity-based; Reward-based (Mollick, 2014).

Vietnam is a potential developing country compared to other Asian neighboring countries. The World Bank has evaluated that Vietnam has the advantages of having a rapidly growing GDP and economy. Other aspects such as the healthcare system, society-wide, education outcomes have been improved in recent years. The rates of extreme illiterate cases or poverty have been declined gradually. Moreover, according to the World Bank report, in terms of financial inclusion, more and more people, especially adults and youngsters, have bank accounts and possess a smartphone, with $40 \%$ of the Vietnamese expected to have this device by 2021 . This means, soon, technology-based subjects and definitions would no longer be unfamiliar and separated in human life. And so is to fintech in general and crowdfunding platforms in particular.

Although there are various studies on CF developed countries, only a few studies on this field are conducted for a fast-growing market like Vietnam due to the small amount of data (Tran T.T. Tu et al. (2018)). If a lot of enormous and professional crowd-funding platforms (CFPs) exist 
worldwide such as Kickstarter (KS) and Indiegogo (IGG) - two of the largest CFPs, there are only $3 \mathrm{CF}$ online platforms with small scale established and processed in Vietnam, which are Fund Start, Betado, and Comicola. Therefore, the aim of this research is to study and understand more about critical features affecting the success of CF campaigns in Vietnam. Moreover, it would be expanded to a larger scale about cases on the world level, specifically to other $\mathrm{CF}$ platforms and CF campaigns popular in other developed countries. The study would be tested by making a separate and all-together analysis between Vietnam and foreign crowdfunding database. We try to see what people should be truly aware of those pivotal determinants which are dramatically able to appeal backers. Existing and other future CF platforms in Vietnam will know which features should they eliminate and/or supplement in their platforms so that they would properly attract backers. It is known that developed countries are advanced in many kinds of fields (such as education, technology, science, entertainment) and CF campaign owners in Vietnam can learn from them. This expansion is to find the similarities and differences between advanced CFPs in developed countries towards the emerging CFPs in Vietnam.

This study's structure is as follows: After the introduction, the subsequent chapter presents some information regarding the crowdfunding platform's structure of Vietnamese platforms and Kickstarter platform. We chose Kickstarter because it is the world's largest online crowdfunding platform and sufficient for our study. And it is the only platform that allows us to explore further information on the expired campaigns. Next, the literature review would mention several theoretical frameworks regarding the main research analysis of this study, and then propose the primary researcher's hypotheses. To continue, in the fourth chapter, data description, information, explanation of variables, and methodology would be illustrated in detail. The research results and discussions are thereafter explained and summarized in the fifth part. After having discussed the study's outcome, the research then closes with concluding remarks, an outline of future research possibilities and discussing the limitations of this research.

\section{STRUCTURE OF CROWDFUNDING PLATFORMS}

Vietnam is recognized as an emerging and fast developing market. Besides, the contradictory culture, different educational system compared to those in Western countries are the huge obstacle preventing the development of CF in Vietnam. There were a few successful pioneer Vietnamese CFPs in the past. Due to some unexpected issues such as financial trouble to maintain the website, language barrier, lacking in experience on managing and operating CFP, technical and security issues, like data stolen, or even be hacked and appropriated by anonymous, not many pioneer platforms are still able to exist until now. Three prestigious and widely-known reward-based CFPs in Vietnam are Fund Start (fundstart.vn), Betado (betado.com), Comicola (comicola.com). These platforms were chosen in order to be compatible 


\section{International Journal of Social Science and Economic Research}

Volume: 05, Issue: 07 "July 2020"

with Kickstarter platform, which only provides the reward-based model. These create fair places to leverage many potential projects from diversified industries. Specifically, by contributing a particular amount of money, backers would then be able to receive an appropriate reward after the campaign raises enough money which meets the target amount. Otherwise, the project owners must refund to all backers in the event of not meeting the initial needed goal. In this case, it is called AON (All-or-nothing) form (Leboeuf, G., Schwienbacher, A., Cumming, D., 2019).

Basically, most CFPs in Vietnam opens for all projects satisfying the input policies in the platform, and the reward-based model is the main choice of most CF campaigns. In general, as the establishment of CFPs in Vietnam is all for the purpose of helping mature and ambitious projects, and each platform has their targeting industries for particular projects and appropriate expertise for those industries, thereby, it is less competitive in the CF market in Vietnam compared to US market.

Similarly, Kickstarter is a CFP which mainly supports the potential ideas of many kinds of projects, especially the creative ones. The list of projects' categories varies from different fields such as documentaries, publishing (books, comics, writing), dancing, gaming. KS serves exactly like many other CFPs in the world. The reviewing process at the beginning is very strict, which requires the projects must satisfy all of KS's rules and some specific criteria. KS does not have the responsibility to check and completely guarantee whether the campaigners surely can finish the project after the CF ends. Once it is approved by the judging team, the campaigners only have to create the funding site, design the campaign site, and post the appropriate information like the needed goal, the maturity date. Doing the marketing via as many channels as possible, updating the information of the product or service's progress, attracting as many backers as possible, etc. Hardly has the campaign successfully reached the funding goal and been expired when the contributing accounts of all backers are charged. And the total raised fund will be deducted by $5 \%$ as a fee paid for KS.

KS only offers the AON model for all reward-based CF campaigns, which is compatible with the aspects of the Vietnamese data. If the campaigns do not attract enough backers and do fail on reaching the funding goal, the project owners do not need to pay the 5\%-fee to KS, and they also cannot gain anything from the contributed money from backers. All the money will automatically refund to all backers' credit cards. It is suggested that before launching any CF campaigns, people should meticulously calculate and estimate all the possible costs and campaign duration spent on the project. The cost may include everything from fixed costs to unexpected payments, even the shipping fees to deliver the rewards to all backers. Time for launching a campaign could be varied from at least 1 day to the maximum of 60-day lasting. They will not be allowed to do any adjustments regarding the funding goal and maturity. Lastly, if 


\section{International Journal of Social Science and Economic Research}

ISSN: $2455-8834$

Volume: 05, Issue: 07 "July 2020"

anything negatively affects the project's process, either during the campaign or after a successful campaign, it will be the project creators' duty to make the announcements in the "Updating" section of the campaign site. It is dramatically necessary for all campaigners to be transparent and clear towards all backers.

\section{THEORY AND HYPOTHESES}

Many theoretical and empirical research, papers on crowdfunding topics have concentrated on critical success determinants on reward-based CFPs; those research analyses were deeply studied by Mollick (2014), Columbo et al., (2015), Chemla and Tinn (2017), Tran et al., (2018). Backer is one of the most important factors which significantly affects the final result of a campaign in crowd-funding. This term refers to the total number of people who support and invest in the fundraising project. Many authors, such as Mollick (2014), Ahler et al. (2015), and Leboeuy et al. (2019) discovered that the number of backers is significantly correlated to the success rate of the project. It also was suggested that by posting project owner's information, the success rate of the project would be affected immediately (Colombo et al. (2015), Ahler et al. (2015), Leboeuy et al. (2019)). To achieve the funding target, the project owner needs to attract as many people as possible, make it more convincing. Therefore, before starting presenting the project, the founders have to introduce themselves first. Some brief information about the founder might be helpful to increase the trustworthiness, connection, and honesty between the project owner and the potential project backers, such as the full name, educational background, age, profile picture, etc. In addition, the crowd always checks on the target funding goal before giving any investing/donating decisions. Moreover, it has been proved that the higher the goal initially set by the founder, the lower the success rate of the project can obtain (Mollick (2014), Ahler et al. (2015), Leboeuy et al. (2019)). Besides, in terms of the CF campaign's length, Kickstarter points out that the longer the duration of a CF project is, the more chances the project owner has to achieve the goal. On the other hand, Mollick (2014) argued that the length of the CF campaign does not ensure the result could be positive. However, it does make sense that campaigns having a very long duration for raising funds do not surely reach the funding target if there is not enough impression during the campaign period. Besides, it is important for the project's detailed information on how the project owner uses and distributes the raised money for the project after the campaign ends in case of successfully achieving the target. This would build the trust of the funders on the project since they know how their money is used and spent for a reasonable and specific place. Chueng et al. (2008) asserted that the more detailed and helpful the description of a CF project has, the higher the success rate the campaign may have.

Team size is another concerned internal factor of the CF campaign affecting its success. The total number of members launching the campaign was also taken into consideration. Because of the 


\section{International Journal of Social Science and Economic Research}

Volume: 05, Issue: 07 "July 2020"

heavy workload a project has, the scale of the team size could positively affect the success of the project (Surowiecki, J. (2004), Chueng et al. (2008), Koch et al. (2015), N. Wang (2017)). Personal contact is also another important determinant. Tran T. T. Tu et al. (2018) also found that personal email attached together with the project's description of the campaigner for backers (which allow them to ask privately for further information on the project) is significantly positively correlated to the success of CF campaign in Vietnam. Apart from the way of approaching potential backers by its uniqueness and differentiation of marketing adverts, the length of the project's main description is also of paramount importance. According to Chueng et al. (2008), the project's initial motivations, future plans, etc. would help the readers to have a clearer view of what they are going to donate money for. However, due to the risk of not collecting anything after the campaign ends, founders tend to give more info on the description part of the project's main page, which is concerned to be irrelevant or redundant information. A sufficient amount of information and presented in an easy and clear organization to read and follow are a great bonus for the campaign.

Furthermore, the number of contributing options would correspond to the number of reward levels regulated initially by the project creators. This is one of the most appealing that the project could draw attention to the crown, also differentiate it with other CF projects (Ahler et al., 2015). Loboeuf et al. (2019) also emphasized that the more reward options a campaign has, the more suitable options the backers can choose and invest in. Empirically, it is undisputed that people prefer something which they could imagine in their minds. Unnava and Burnkrant (1991) demonstrated that people may absorb and recall information through visualization items more efficiently and quickly than simply through a normal document. Posting one or two videos regarding the project together with pictures and descriptions would also boost the success rate of the campaign. The provision of pictures does draw people's attention much easier than by words (Glenberg and Langston, 1992). It is a huge advantage to the campaign if it is fully presented the description in terms of documents, videos, and pictures. It was found that such physical media items are positively related to the length of visiting duration of a website and the number of viewers (Danaher et al., 2006). Another recent study has shown that if the project does not have any video, people may feel less interested in continuing reading and learning more about it, regardless of how potential the project is (Koch and Siering, 2015).

In fact, not many studies pay much attention to find out more factors affecting the success rate or expand the research to macro levels in which crowdfunding activities are involved. Apparently, the development of a country would follow by the growth of many other industries, including a niche funding market like crowdfunding. As aforementioned above, there recently have been a variety of authors having done researches on typical success determinants on crowdfunding campaigns of the authors' countries; see Mollick (2014), Columbo et al., (2015), Chemla and 
Tinn (2017), Leboeuf et al., (2019). However, there has been only one study so far, which indicates the success factors that influencing CF campaigns in Vietnam conducted by Tran T. T. $\mathrm{Tu}$ et al. (2018). It could be other factors or correlations which could be continued studying regarding the success of $\mathrm{CF}$, especially a developing market like Vietnam.

H1: There are typical determinants on the success of crowdfunding projects.

To test Hypothesis 1, a list of research variables with their corresponding hypotheses is shown in table 1.

Table 1: Summary of research variables and hypotheses

\begin{tabular}{llll}
\hline No. & Factors & Variables & $\begin{array}{c}\text { Hypothetical } \\
\text { impact }\end{array}$ \\
\hline 1 & Success Dummy & successdummy & founderinfo \\
2 & Project owner's information & contact & Positive \\
3 & Project owner's contact & innodum & Positive \\
4 & Innovative projects & creativedum & \\
5 & Creative projects & goal & Positive \\
6 & Fund needed & duration & Positive/Negative \\
7 & Duration (days) & costinfo & Positive \\
8 & Project's costs detail information & backer & Positive \\
9 & Total Backers & teamsize & Positive \\
10 & Team Size & reward & Positive \\
11 & Full-Text Length & textlength & Positive \\
12 & Visualization Items & visualization & Positive \\
13 & Further Information Access & infoaccess & \\
\hline & (Source: Summarized and estimated by the author) &
\end{tabular}

Besides, this research would be kept up by making a separate and all-together analysis between Vietnam and foreign crowdfunding databases to figure out whether there are similar and different characteristics in terms of the influence factors towards the crowdfunding campaign's success. 


\section{DATA AND METHODOLOGY}

\section{Data summary and variables description}

The collected CF database used for this research is only concentrating on CF campaigns applying and following a reward-based model from Vietnamese CFPs and Kickstarter. In fact, among 4 types of popular online CF forms (reward-based, lending-based, donation-based, equity-based), the rewarding form is the most efficient, widely-used, and dominant model asserted by a variety of scholars such as Mollick (2014), Dushnitsky et al. (2016), N. Wang et al. (2017). Being the source of the fast growth model, this CF base accounts for a major percentage in the CF industry. The backers would then receive physical rewards described in the project rather than literally an amount of financial return or actual money like other models. They could be in the form of nonmonetary rewards such as goods, services, discounts related to the supported project of the campaign, or simply an acknowledgment, in exchange for the contribution. In other words, this is very similar to pre-ordering, which Beaulieu et al. (2015) referred to as the cause of the overlapping, to some extent, with the online purchasing platform. The reward-based model is the best fundraising form which reflects the true meaning of online crowdfunding. 
International Journal of Social Science and Economic Research

ISSN: $2455-8834$

Volume: 05, Issue: 07 "July 2020"

Figure A: Histogram of Data Distribution by Typical Platform Overtime

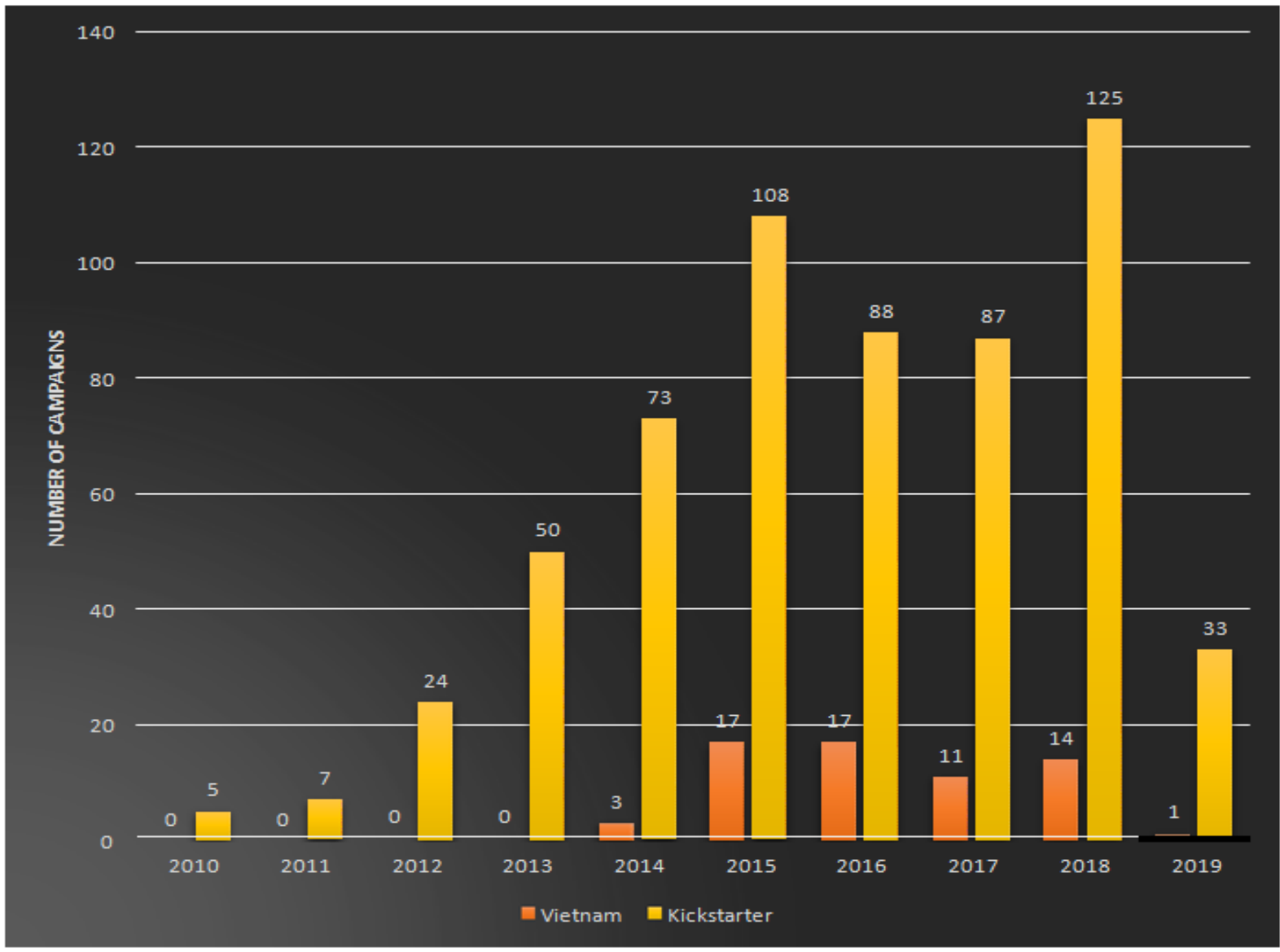

The bar chart below shows a deeper and closer understanding regarding the accurate number of CF campaigns of each platform (Vietnam and Kickstarter) over the period from 2010 to 2019 of the database.

The data set for the extending research of foreign $\mathrm{CF}$ campaigns processing in developed countries was collected manually, ranging from 2010 to 2019, from the world-largest crowdfunding site: Kickstarter (kickstarter.com). In Vietnam, the data was collected manually process of $\mathrm{CF}$ campaigns from three currently existing and the most famous crowdfunding platform websites: Fundstar.com, Comicola.com, and Betado.com. 2014 remarked as a year of several CFPs successfully established and have been maintaining the funding operation until now. Therefore, the Vietnamese data ranges over the period from 2014 to 2019. Because of the fact that there is not much attention, also the difference in cultures, hence, the collected data from Vietnamese platforms is relatively small compared to the one collected from Kickstarter in terms of the total sample. In the beginning, there were 1000 campaigns in this study's full data 
sample. After processing the entire database, those which did not comply to the required conditions of the study were eliminated immediately (for instance: the campaign's duration is less than 20 days; the funding goal is less than $\$ 1000$ or greater than $\$ 2,000,000$ for campaigns on $\mathrm{KS}$, or there were some campaigns which violated the CFP's policies or were canceled by themselves). As a result, there are 63 and 600 qualified CF campaigns collected from Vietnamese CFPs and Kickstarter, respectively, in the data set. As shown in figure B of the Data Distribution Description section, approximately $23 \%$ and $77 \%$ of the projects in the final data sample of this work belong to the Innovative and Creative category, respectively. It also demonstrates from figure $\mathrm{C}$ that the number of successful creative projects (359 projects) is much higher than that of the successful innovative projects (56 projects).

Figure B: Completion ratio Histogram by Platforms

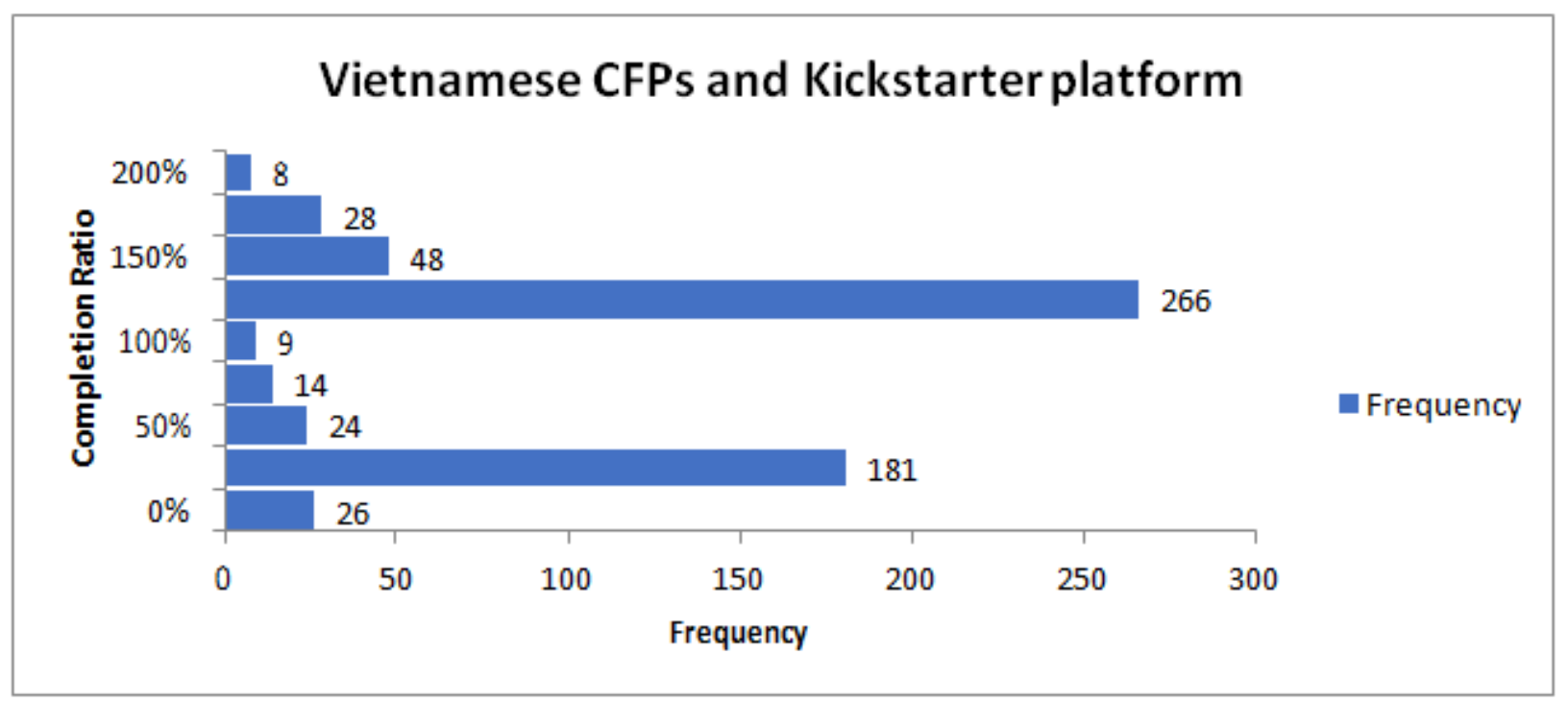


International Journal of Social Science and Economic Research

ISSN: 2455-8834

Volume: 05, Issue: 07 "July 2020"
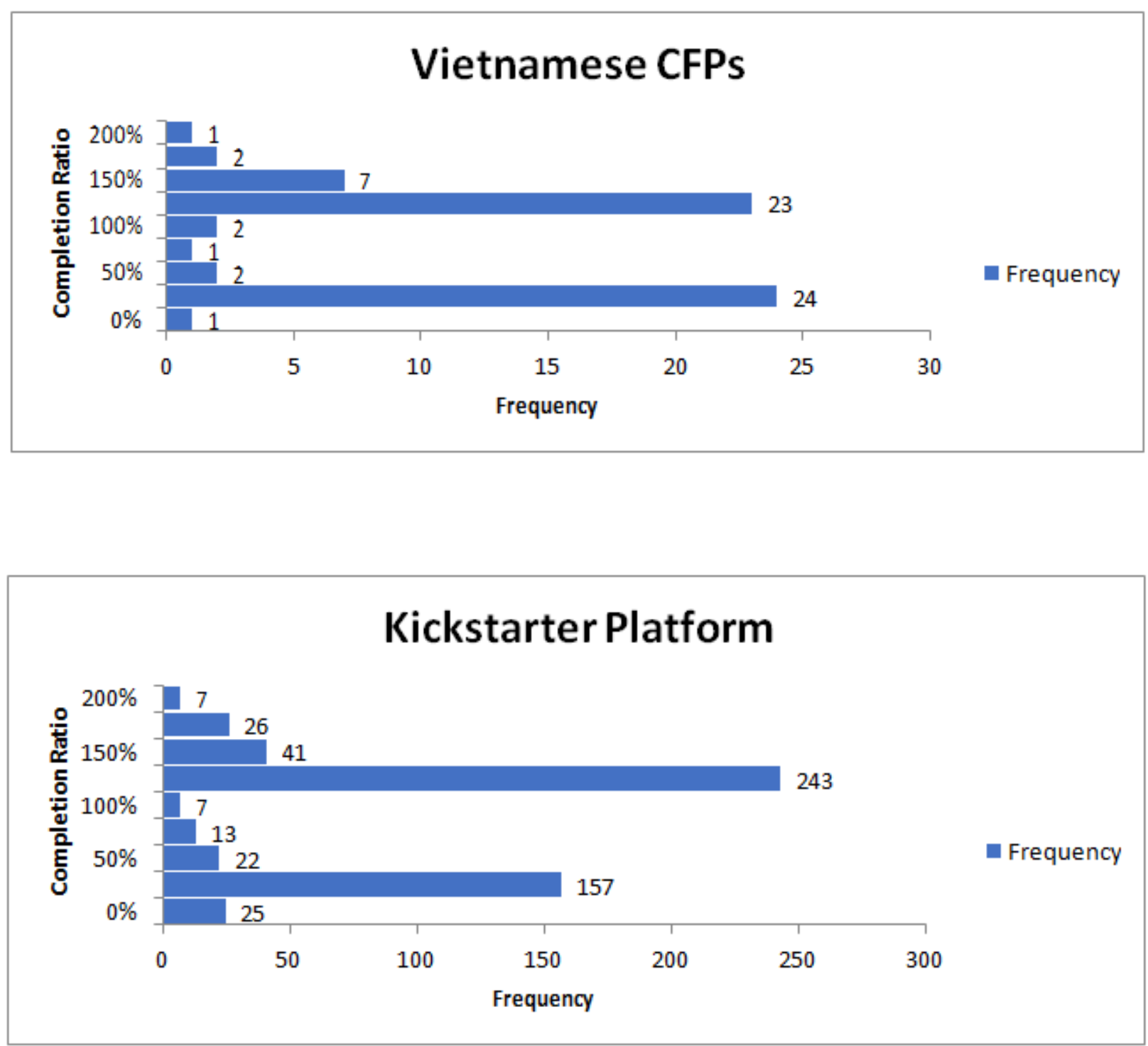


\section{Figure C: Data Distribution by Types of Category}

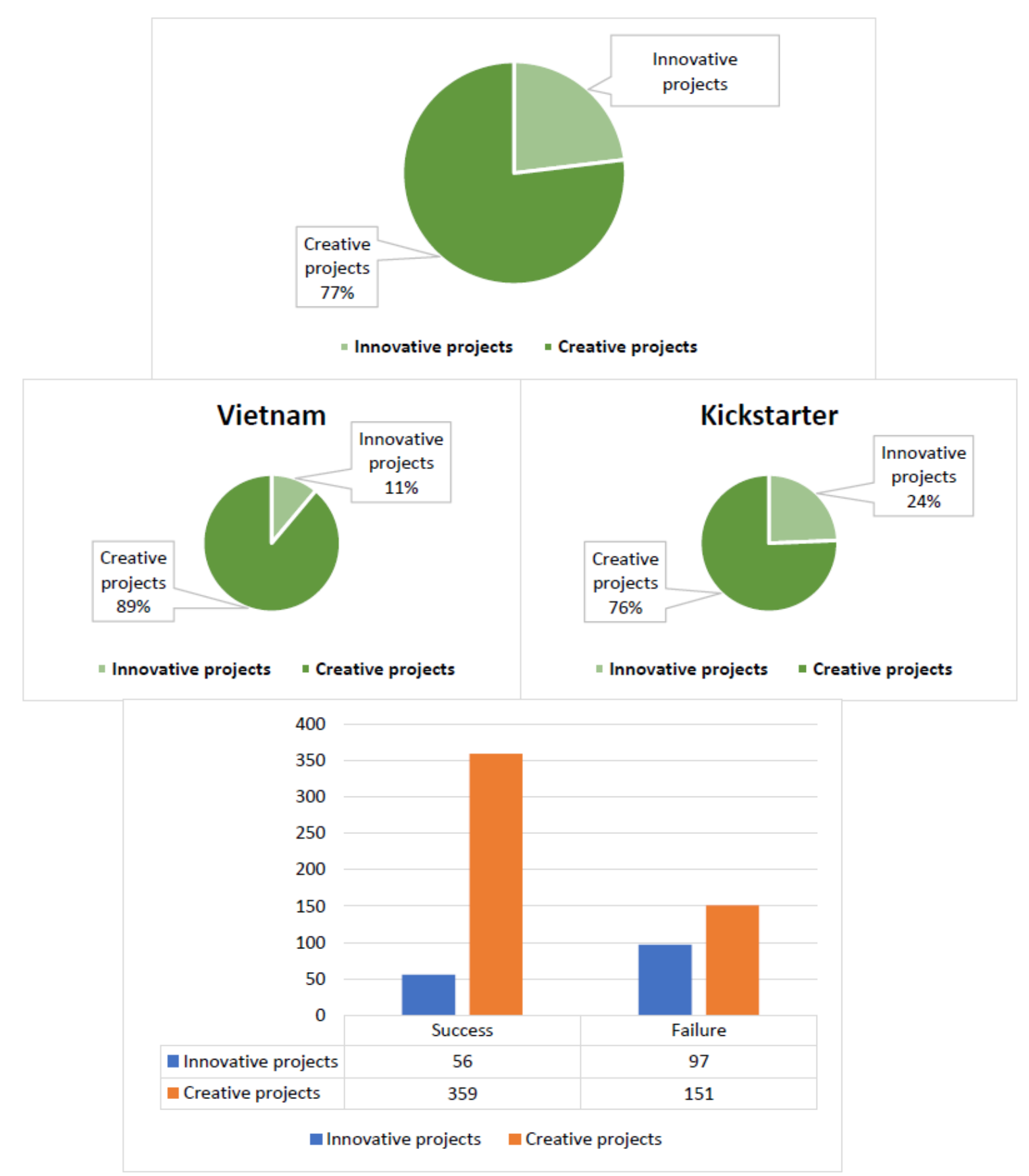

The first pie chart below shows the percentage between the number of Innovative projects and the number of Creative projects structured in my research database. Moreover, these two categories are also clearly classified towards the Vietnamese CFPs and Kickstarter platform. 
The research contains 14 variables. The data and related information campaigns of these variables were published online on CFPs. Although the data from Kickstarter is relatively difficult to find the source due to being hidden, all are still fundamentally available to access until the study period. Besides, in order to be concerned as valid data for collecting, it has to comply with some rules:

$\checkmark$ The campaigns in CFPs must already end, no matter what the result is (success or failure).

$\checkmark$ To avoid the unexpected outliners, the funding goals of the campaigns processing in Kickstarter are only collected once they range from $\$ 1000$ (one thousand dollar) to $\$ 2,000,000$ (two million dollar).

$\checkmark$ To avoid the phenomena of testing or collecting feedbacks, attention of the crowd, campaigns which lasted less than 20 days shall be omitted from the sample.

$\checkmark$ Recorded variables included are required to be "quantity" variables. This would also be a cross-section analysis and concerned to be discrete data since it is collected from many CF campaigns, which vary from fields to fields.

$\checkmark$ Any disqualified, suspended campaigns rejected by the platform or campaigner are removed straight away from the data sample.

\section{Dependent variables:}

Dummy success (successful or failed): This variable is equal to " 1 " corresponding to the manifestation of a successful fundraising campaign, or "0" vice versa. Since Vietnamese CFPs and Kickstarter only follow the AON ("all-or-nothing") model, which means after the CF campaign ends, the project owner would only be able to collect the funded amount from the backers providing that the campaign's initial target goal needed is achieved (either be equal or higher than the amount set by the project owner at the beginning of the campaign). Otherwise, nothing would be collected. Simply speaking, the campaign must be successful in order to have money to proceed with the plan of the project.

\section{Independent variables:}

1. Project owner's Information: This variable is equal to "1" corresponding to a campaign including the founders, creators, or project owners' personal information which makes their campaigns reliable or worth investing such as their educational background, related experience, pictures or information about their previous products or achievements, varified certificates. Otherwise, this variable is subject to " 0 ". Some brief information about the founder might be helpful to increase the trustworthiness, connection, and honesty between the project owner and the potential project backers, such as the full name, educational background, age, profile picture. 
2. Project owner's contact: This variable is equal to " 1 " corresponding to a campaign having the email and/or phone number of the campaigners. Otherwise, this variable is subject to " 0 ". This is concerned to be another way to enhance the trust of the crowd by publicly announcing the personal phone number, email, or the info of the creators' personal social network. By doing this, funders would be able to directly contact and speak with the founder, and understand more (i.e. unclear information) about the project.

3. Innovative projects: Dummy variable refers to projects belonging to the "Innovative" category, which are from the following list of sub-categories: Food, Technology. This variable is equal to " 1 " if the project is subject to the innovative category, or " 0 " if the project is subject to the creative category.

4. Creative projects: Dummy variable refers to projects belonging to the "Creative" category, which are from the following list of sub-categories: Art, Comics, Crafts, Dance, Design, Film and Video, Games, Jounalism, Music, Photography, Publishing, Theater. This variable is equal to " 1 " if the project is subject to the creative category, or " 0 " if the project is subject to the innovative category.

5. Funding goal (Goal): This is the minimum amount of money a successful project needs to achieve and continue proceeding with the plan. It is the most critical and important factor affecting the final result of the campaign. US Dollar is the main current to be used in the research. Any other projects funded by other currencies would be converted to USD based on the annual average exchange rate.

6. Duration: This variable refers to the specific range of periods the $\mathrm{CF}$ project lasts to raise fund from the crowd. And this variable would be recorded as "month" (presumably 1 month $=30$ days $)$.

7. Project's costs detail information: This variable receives the value of " 1 " if the campaign creators did show which kinds of costs distributing to their project. Otherwise, this variable equals " 0 ".

8. Total Backers: This is the total number of people who support and invest in the fundraising project.

9. Team Size: This is the number of people in a team of the project who together operate and conduct the project. Besides, due to the fact that there are some projects which are created by a legal entity or an organization such as a club, a company, a restaurant, a community, or even by an unidentified team structure regarding the number of members involving. For those special campaigns, we consider them as one legal person and set to " 1 ".

10. Funding Levels (Levels of reward): The total number of rewarding options/choices that the project's owner offers at the beginning of the campaign to the backers. Each funding level is corresponding to a specific amount of contributing level of investment that the backers can choose to back/support. 
11. Full-Text Length (in characters): This variable displays how many words are presented or written in a campaign by the project creators. It is noted that only the words, sentences, statements, paragraphs related to the main content, title, the description, details of the cost distribution, the risk anticipation, etc. of the project will be scanned through and counted.

12. Visualization Items: This variable illustrates the total number of images, pictures, video materials, and/or relevant media items attached to the project's description on the main CF site, to present the project owner's idea to the crowd.

13. Further Infomation: This variable refers to the total number of external links for backers' further reviews regarding the projects or the campaigners such relevant online articles, project's updating information, or social networks related to the project such as Facebook, Twitter, Instagram, where the campaigner posts more specific information, progress, announcements, news, pictures, videos, achievements, etc., anything about the progress of the project. Those external links which are presented repeatedly on the project's main page would be not counted again.

The summary of our variables is displayed in Table 2.

Table 2: Description of Variables

\begin{tabular}{|c|c|c|}
\hline $\begin{array}{c}\text { Project Charateristics } \\
\text { Variables }\end{array}$ & Definition & Variables \\
\hline $\begin{array}{l}\text { Project owner's } \\
\text { information }\end{array}$ & $\begin{array}{l}\text { Campaign creator's background, information; i.e., } \\
\text { education, experience, previous accomplishment }\end{array}$ & founderinfo \\
\hline Project owner's contact & $\begin{array}{l}\text { Campaign creator's private contact; i.e., phone number, } \\
\text { email, address }\end{array}$ & contact \\
\hline Innovative project & $\begin{array}{l}\text { Binary variable equals "1" if the project is subject to } \\
\text { innovative sub-categories, or " } 0 \text { " vice versa; i.e., Food, } \\
\text { Technology }\end{array}$ & innodum \\
\hline Creative project & $\begin{array}{l}\text { Binary variable equals "1" if the project is subject to } \\
\text { creative sub-categories, or "0" vice versa; i.e., Art, } \\
\text { Comics, Crafts, Dance, Design, Film and Video, Games, } \\
\text { Journalism, Music, Photography, Publishing, Theater }\end{array}$ & creativedum \\
\hline Funding goal & $\begin{array}{l}\text { The CF campaign goal (in USD or converted to USD } \\
\text { based on the corresponding annual average exchange } \\
\text { rate) set by the campaign creator at the beginning }\end{array}$ & goal \\
\hline Funding level & $\begin{array}{l}\text { Number of reward levels offered by the campaign } \\
\text { creator }\end{array}$ & reward \\
\hline Duration & $\begin{array}{l}\text { Duration of the CF campaign (measured in months) and } \\
\text { set by the project owner at the beginning }\end{array}$ & duration \\
\hline
\end{tabular}


International Journal of Social Science and Economic Research

ISSN: 2455-8834

Volume: 05, Issue: 07 "July 2020"

\begin{tabular}{|c|c|c|}
\hline Team size & Number of members progressing the project & teamsize \\
\hline $\begin{array}{l}\text { Project's costs detail } \\
\text { information }\end{array}$ & $\begin{array}{l}\text { Detail information about the cost structure using for } \\
\text { conducting the project }\end{array}$ & costinfo \\
\hline Full text length & $\begin{array}{l}\text { Length (in characters) of the full text of the project } \\
\text { relevant description on the project's main page }\end{array}$ & textlength \\
\hline Visualization items & $\begin{array}{l}\text { Total media items posted on the project's main page; } \\
\text { i.e., images, pictures, videos }\end{array}$ & visualization \\
\hline Further information & $\begin{array}{l}\text { Total number of suggested links; i.e., further relevant } \\
\text { infomation, updating information }\end{array}$ & infoaccess \\
\hline Success Dummy & $\begin{array}{l}\text { Binary variable equals " } 1 \text { ", if the completion ratio is } \\
\text { equal or greater than } 1 \text {, and is thus considered as } \\
\text { successfully financed. Otherwise, it is " } 0 \text { " }\end{array}$ & successdummy \\
\hline Amount of raised fund & Sum of all pledges made by backers & moneyraised \\
\hline Completion ratio & $\begin{array}{l}\text { Ratio between the total amount of raised fund and the } \\
\text { funding goal; i.e., the ratio of the variables Money }\end{array}$ & ratio \\
\hline Total backers & $\begin{array}{l}\text { Total number of backers having pledged money to the } \\
\text { project }\end{array}$ & backer \\
\hline
\end{tabular}

\section{METHODOLOGY}

The best fit researching method used for this work will rely on quantitative analysis. More specifically, a cross-sectional study will be conducted on the discrete data as this method help the researchers be able to discover a particular phenomenon ( $\mathrm{CF}$ critical success factors) at a particular period (Saunders et al., 2009). Moreover, since it enhances the opportunity to obtain the descriptive information, this kind of analysis was designed to help build accurate theories in regard to the study while creating a base to help later researchers continue conducting and developing further analyses. The probit analysis model is used to analyze those above variables.

Moreover, the key-dependent variable of this research is the outcome of the CF campaign (Success dummy), which is known as a binary variable. That is the reason why the Probit regression is used to be the first method. 
Hypothesis: There are typical determinants on the success of crowdfunding projects.

$\mathrm{CFS}=\alpha+(\text { Founder info })^{*} \beta_{1}+($ Contact $) * \beta_{2}+($ Innovative dummy $) * \beta_{3}+($ Creative dummy) ${ }^{*} \beta_{4}+(\text { Goal })^{*} \beta_{5}+(\text { Duration })^{*} \beta_{6}+(\text { Project costs info })^{*} \beta_{7}+($ Backer $) * \beta_{8}+($ Team Size $) * \beta_{9}+($ Reward Level $) * \beta_{10}+($ Text Length $) * \beta_{11}+($ Visualization $) * \beta_{12}+($ Info Access $) * \beta_{13}$

$$
+\varepsilon
$$

$$
\text { Or: } \mathrm{CFS}=\alpha+\sum_{\mathrm{i}=1->\mathrm{n}}\left(\beta_{\mathrm{i}}^{*} \mathrm{X}_{\mathrm{i}}\right)+\varepsilon
$$

where CFS: Crowdfunding success dummy (Dependent Variable)

$$
\mathrm{Xi} \text { : Critical factors (Independent Variables) }
$$

\section{RESULTS}

The nature of crowdfunding is gathering capital from individuals from society. Therefore, it is important for the crowdfunding project to attract a high number of backers at first even that high number of backers do not guarantee the success rate of the crowdfunding project. Therefore, we start our research by first testing which factors are determinants of the backer number for Vietnamese platforms, Kickstarter, and the whole sample, respectively. The results are presented in Table 3 below.

Table 3: Determinants of Crowdfunding Backers

\begin{tabular}{lccc}
\hline \multirow{2}{*}{ VARIABLES } & $\begin{array}{c}(1) \\
\text { Vietnam }\end{array}$ & $\begin{array}{c}(2) \\
\text { Kickstater }\end{array}$ & $\begin{array}{c}(3) \\
\text { fulldata }\end{array}$ \\
\hline \multirow{2}{*}{ founderinfo } & & & \\
& 1.843 & -49.51 & -45.58 \\
contact & $(52.75)$ & $(53.52)$ & $(48.27)$ \\
& -7.031 & $127.6^{* *}$ & $132.6^{* * *}$ \\
GOAL & $(48.80)$ & $(51.96)$ & $(45.66)$ \\
& 6.238 & $38.49^{* *}$ & $32.67 *$ \\
duration & $(24.52)$ & $(18.85)$ & $(17.40)$ \\
& -0.634 & 101.7 & 1.578 \\
costinfo & $(0.825)$ & $(63.11)$ & $(1.688)$ \\
& 15.91 & $-85.42^{*}$ & -70.44 \\
& $(47.70)$ & $(49.44)$ & $(43.90)$
\end{tabular}


International Journal of Social Science and Economic Research

ISSN: 2455-8834

Volume: 05, Issue: 07 "July 2020"

\begin{tabular}{lccc} 
teamsize & 5.710 & $33.66 * * *$ & $26.19 * * *$ \\
& $(5.777)$ & $(12.74)$ & $(9.581)$ \\
reward & $30.29 * * *$ & 5.193 & 4.662 \\
& $(10.57)$ & $(3.397)$ & $(3.179)$ \\
TEXTLENGTH & $65.67 *$ & $-79.50 * *$ & $-46.32 *$ \\
& $(33.99)$ & $(33.04)$ & $(26.99)$ \\
visualization & 3.273 & $7.888^{* * *}$ & $8.040^{* * *}$ \\
& $(2.974)$ & $(2.410)$ & $(2.173)$ \\
infoaccess & $15.14 * *$ & $16.87 * * *$ & $15.72 * * *$ \\
& $(6.827)$ & $(2.171)$ & $(1.963)$ \\
innodum & 70.28 & 44.00 & 38.42 \\
& $(78.04)$ & $(51.87)$ & $(48.41)$ \\
Constant & $-747.6 * *$ & -102.6 & -169.8 \\
& $(345.1)$ & $(244.9)$ & $(222.5)$ \\
& & & \\
Observations & 63 & 599 & 662 \\
R-squared & 0.446 & 0.239 & 0.233 \\
\hline
\end{tabular}

Standard errors in parentheses

$* * * \mathrm{p}<0.01, * * \mathrm{p}<0.05, * \mathrm{p}<0.1$

From table 3, we find that projects with visualization, clear goal, a high number of founders, and have more project information to access, will appeal more backers while project duration, type of project, and information of founder have no effect on the number of backers. Particularly, if a campaign meticulously give more detailed and structured information about the project on the main site of the CF campaign such as the general plan, initial motivation, the meaning of the project to everyone, this would help the backers understand more about an investment that they could possibly join in. Only backers from Vietnamese platforms pay attention at reward level in our research. Backers from Kickstarter care more about the way to contact project founders. The more way of contact with to project founder, the greater number of backers is into the project. It seems to be less attractive to backers if the texts describing the project are too long in general and for Kickstarter platform. This sign becomes positive for when we test for Vietnamese platforms only. The summary of significant determinants of backers for crowdfunding project is as follows.

$$
\begin{gathered}
\text { Backers }=\alpha+\beta 1 *(\text { contact })-\beta 2 *(\text { teamsize })+\beta 3 *(\text { visualization })+\beta 4^{*}(\text { infoaccess })+ \\
\beta 5^{*}(\text { GOAL })-\beta 6^{*}(\text { textlength })+\varepsilon
\end{gathered}
$$

We continue our empirical test by using success dummy as a dependent variable subject to a list of 11 independent variables. The first model show results for the Vietnamese case while the 
second and the third model present findings for Kickstarter and both samples, respectively. We find that overall, information access, reward, project goal, founder information, and type of project significantly affect the success rate of all crowd-funding projects while project duration, text length, visualization, and cost information, seem not to play an important role to the campaign.

Table 4: Determinants of Crowdfunding Success

\begin{tabular}{|c|c|c|c|}
\hline VARIABLES & $\begin{array}{c}(1) \\
\text { Vietnam }\end{array}$ & $\begin{array}{c}(2) \\
\text { Kickstater }\end{array}$ & $\begin{array}{c}\text { (3) } \\
\text { fulldata }\end{array}$ \\
\hline founderinfo & $\begin{array}{l}-0.509 \\
(0.513)\end{array}$ & $\begin{array}{c}0.509 * * * \\
(0.180)\end{array}$ & $\begin{array}{c}0.385 * * \\
(0.162)\end{array}$ \\
\hline contact & $\begin{array}{c}-1.217 * * \\
(0.497)\end{array}$ & $\begin{array}{c}0.0197 \\
(0.194)\end{array}$ & $\begin{array}{l}-0.178 \\
(0.163)\end{array}$ \\
\hline GOAL & $\begin{array}{l}-0.515 * \\
(0.280)\end{array}$ & $\begin{array}{c}-0.571 * * * \\
(0.0802)\end{array}$ & $\begin{array}{c}-0.549 * * * \\
(0.0741)\end{array}$ \\
\hline duration & $\begin{array}{l}-0.00982 \\
(0.00703)\end{array}$ & $\begin{array}{l}-0.186 \\
(0.217)\end{array}$ & $\begin{array}{c}-0.00157 \\
(0.00589)\end{array}$ \\
\hline costinfo & $\begin{array}{c}-0.717 \\
(0.506)\end{array}$ & $\begin{array}{l}0.362 * \\
(0.188)\end{array}$ & $\begin{array}{c}0.237 \\
(0.160)\end{array}$ \\
\hline teamsize & $\begin{array}{c}0.0270 \\
(0.0485)\end{array}$ & $\begin{array}{l}0.170 * * \\
(0.0677)\end{array}$ & $\begin{array}{c}0.0779 * * \\
(0.0359)\end{array}$ \\
\hline reward & $\begin{array}{c}0.237 * * \\
(0.116)\end{array}$ & $\begin{array}{c}0.0577 * * * \\
(0.0176)\end{array}$ & $\begin{array}{c}0.0650 * * * \\
(0.0163)\end{array}$ \\
\hline TEXTLENGTH & $\begin{array}{c}0.212 \\
(0.295)\end{array}$ & $\begin{array}{c}-0.0257 \\
(0.115)\end{array}$ & $\begin{array}{l}-0.0656 \\
(0.0909)\end{array}$ \\
\hline visualization & $\begin{array}{c}0.0176 \\
(0.0293)\end{array}$ & $\begin{array}{r}-0.000548 \\
(0.00909)\end{array}$ & $\begin{array}{c}0.00280 \\
(0.00818)\end{array}$ \\
\hline infoaccess & $\begin{array}{l}0.152 * * \\
(0.0677)\end{array}$ & $\begin{array}{c}0.145^{* * *} \\
(0.0159)\end{array}$ & $\begin{array}{c}0.148 * * * \\
(0.0144)\end{array}$ \\
\hline innodum & $\begin{array}{c}-0.397 \\
(0.683)\end{array}$ & $\begin{array}{c}-0.639 * * * \\
(0.178)\end{array}$ & $\begin{array}{c}-0.590 * * * \\
(0.169)\end{array}$ \\
\hline Constant & $\begin{array}{c}2.532 \\
(3.086)\end{array}$ & $\begin{array}{c}3.673 * * * \\
(0.898)\end{array}$ & $\begin{array}{c}3.742 * * * \\
(0.814)\end{array}$ \\
\hline Observations & 63 & 599 & 662 \\
\hline $\mathrm{R} 2$ & 0.274 & 0.469 & 0.425 \\
\hline
\end{tabular}

Standard errors in parentheses 


$$
* * * \mathrm{p}<0.01, * * \mathrm{p}<0.05, * \mathrm{p}<0.1
$$

Based on the Probit regression result, it is explored that Goal is negative and statistically significant. It is reasonable that if the initial funding goal set by the project's owner is too high and the project's plan is not stunning enough, it will reduce the success rate of the campaign. It was also found that the impact of Reward Level, and Information Access are positive and statistically significant. People are usually attracted by incentives. Therefore, it makes sense that the more rewarding options for backers to be able to choose, the more chances that the campaign would be successful. Moreover, backers will feel safer when they sufficiently understand and have a broad view of the campaign's project. Hence, adding more relevant updates, prior achievement, outside news, and information is a wonderful way to help the potential backers understand more about the project. Once they get to know more about the campaign, the probability of success rate would be considerably enhanced. Our results also indicate that projects organized by a large number of founders have a higher chance to be successful in raising funds from the crowd. Besides, creative projects are also more attractive than innovative projects when we find a significant and negative coefficient between innovation dummy and success rate. We can summarize the significant determinants of crowdfunding success for both Vietnamese and Kickstarter sample as follows:

$$
\begin{gathered}
\mathrm{CFS}=\alpha+* \text { founderinfor }-0.549 *(\text { goal })+0.065 *(\text { reward })+0.148 *(\text { infoaccess })+ \\
0.0779 *(\text { teamsize })-0.590 *(\text { innodum })+\varepsilon
\end{gathered}
$$

However, when running the empirical test separately for the Vietnamese platform, we find that besides the goal, reward, and information access, the project ower contact does play an important role to project success rate. A negative relation between owner contact and success rate. It seems if project owners provide too much contact information on the website, it will reduce the probability of success rate. The reason maybe if they provide too many contact means, it is hard for them to control and reply to backers on time. On the other hand, as mentioned above, the project owner's contact is not significantly important to the success rate for a broader sample - the Kickstarter platform. Instead of that, when we run the empirical test for Kickstarter, founder information is important and positively significant to the success rate. The more information the project founder provides, the higher rate of success. Finally, only backers from Kickstarter care about whether the project is innovative or creative. The negative We find from Kickstarter that backers, who are already in the project, will support more for the creative project while it is not important for backers from Vietnamese platforms.

\section{CONCLUSION AND RECOMMENDATION}

Looking closer to the result of the study's analysis, our paper continues to shed the light on 


\section{International Journal of Social Science and Economic Research}

ISSN: $2455-8834$

Volume: 05, Issue: 07 "July 2020"

determinants that appeal to the backers and enhance the success of the crowdfunding campaign. The paper indicates that the duration of the project and the structure of the project cost are not important to backers and have no significant impact on the success of the crowdfunding project. To attract more backers into the project, the use of effective visualization such as illustrative videos, pictures of real project samples or prototypes are encouraged and positively significant. In addition, project founders should actively show further news, information about the raising campaign via other sources such as Facebook or social media so that the information of the project could reach everyone, especially the potential backers. However, to raise funds successfully from the crowd, the project's founders need more than that. Besides setting an appropriate funding goal, getting more attention by various stunning levels of reward, and showing clear information of the campaign's founder, a considerate and determinate project's owner should also consider how long the description and information of their project would be sufficient.

Furthermore, even the breakout of cost structure might distract backers from the beginning (negative sign of cost information with the number of backers), it becomes important for a project to be successful in raising funds from crowdfunding. In our opinion, when a demander needs money and wants to raise funds whosoever from any forms of financing sources (like bank, private fund, or even family or friends), the clearness and transparency of cost's distribution to the project should be taken as a priority thing. It proves that the project's owner has prepared everything needed relating to the financial process of the entire plan well, and he/she only needs enough money to operate the project. Moreover, when disclosing the expenditure of the cost structure, backers and people who support you with money would feel safer and be more guaranteed when they know which purposes and where the money they invested would flow to. And by building trust, for several cases, the project's owners could also gain many useful feedbacks and comments regarding the further improvement, extra idea of products (or services) or even future cooperation (Cheung et al., 2008; Mudambi and Schuff, 2010)

To wrap things up from this study, according to the result of this study and empirical researches, by observing both successful and failed cases during the time of manually collecting data of every single campaign, there are some fundamental and critical characteristics affecting on the success of CF campaigns, which cannot be ignored on the main sites of the campaigns:

$\checkmark$ Clear and concise project's description if possible

$\checkmark$ Relevant and needed information on the project's owner personal information

$\checkmark$ Estimate realistic visualization and funding goal to attract backers and reasonable payback rewards (Wheat, et al. 2013 p. 71)

$\checkmark$ Consider the length of the time raising fund on CFP 
$\checkmark$ Public talks can be considered to get attention and spread the motivation, ambition from the project's owners to the public (Blohm, et al. 2013, p.79)

$\checkmark$ Update the project's progress on the main site of the campaign and email to announce every current backer if possible

\section{REFERENCES}

Ahlers, G. K., Cumming, D., Günther, C., \& Schweizer, D. (2015). Signaling in Equity Crowdfunding. Entrepreneurship Theory and Practice, 955-980.

Beaulieu, T., Sarker, S., Sarker, S. (2015). A conceptual framework for understanding crowdfunding. Communications of the Association for Information Systems.

Blohm, I.; Leimeister, J. M. \& Krcmar, H. (2013): Managing Open Innovation Communities Development and Test of an Innovation Community Scorecard. In: Open innovation in the food and beverage industry: Concepts and case studies. Hrsg./Editors: Garcia Martinez, M. Verlag/Publisher: Woodhead Publishing, Woodhead, Cambridge, UK. Erscheinungsjahr/Year: 2013. Seiten/Pages: 216-234

Chemla, G. and K. Tinn, K. 2017, "Learning Through CF, ”

Collins, L., \& Pierrakis, Y. (2012). The venture crowd: CF equity investment into business. London: Nesta

Colombo, M. G., Franzoni, C. \& Rossi-Lamastra, C. (2015). Internal Social Capital and the Attraction of Early Contributions in Crowdfunding. Entrepreneurship Theory and Practice, 39, 75-100

Cheung, C. M., Lee, M. K. \& N. Rabjohn. (2008). The impact of electronic word-of-mouth. Internet Research 18(3), 229-247

Danaher, Peter \& W Mullarkey, Guy \& Essegaier, Skander. (2006). Factors Affecting Web Site Visit Duration: A Cross-Domain Analysis. Journal of Marketing Research. 43. 182- 194.

Dushnitsky, G., Guerini, M., Piva, E., Rossi-Lamastra, C., 2016. Crowdfunding in Europe: Determinants of platform creation across countries. California Management Review 58, 44-71

Glenberg, A. M., \& Langston, W. E. (1992). Comprehension of illustrated text: Pictures help to build mental models. Journal of Memory and Language, 31(2), 129-151. 
Koch, Jascha-Alexander, Siering, Michael. (2015). Crowdfunding success factors: The characteristics of successfully funded projects on crowdfunding platform.

Leboeuf, G., Schwienbacher, A., Cumming, D. (2019). Crowdfunding Models: Keep- It-All vs. All-Or-Nothing.

Mollick, E., 2014. The dynamics of crowdfunding: An exploratory study. Journal of Business Venturing 29, 1-16.

Moncada-Paternò-Castello, P., Vezzani, A., Hervás, F., \& Montresor, S. (2014). Financing $R$ \& $D$ and innovation for corporate growth: What new evidence should policymakers know? Seville, Spain: European Commission, Joint Research Centre - Institute for Prospective Technological Studies

Mudambi, S.M., and Schuff, D. 2010, "What makes a helpful online review? A study of customer reviews on Amazon. com," MIS Quarterly (34:1) pp 185-200

N. Wang, Q. Li, H. Liang, T. Ye, S. Ge, Understanding the importance of interaction between creators a and backers in crowdfunding success, Electronic Commerce Research and Applications (2017), available at: https://doi.org/10.1016/j.elerap.2017.12.004

Surowiecki, J. (2004). The Wisdom of Crowds. Why the Many Are Smarter Than the Few, 5th edition. Abacus, London.

Tran T. T. Tu, Dinh P. Anh, \& Tang T. H. Thu (2018). Exploring Factors Influencing the Success of Crowdfunding Campaigns of Startups in Vietnam. Accounting and Finance Research, Sciedu Press, Vol. 7, No. 2.

Unnava, H \& Burnkrant, Robert. (1991). An Imagery-Processing View of the Role of Pictures in Print Advertising. Journal of Marketing Research. 28. 226. 10.2307/3172811.

\section{Websites}

https://www.kickstarter.com

https://www.fundstart.vn/

Character Count Online: https://www.charactercountonline.com/ 